\title{
FIRST DAYS OF MARTIAL LAW IN NOWA HUTA
}

\author{
PIOTR KAPUSTA \\ piotr.kapusta@uj.edu.pl \\ Jagiellonian University Kraków \\ Poland
}

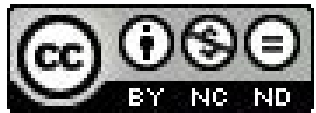

\begin{abstract}
The theme of my work is related to the thirtieth anniversary of the introduction of martial law in Poland on the $13^{\text {th }}$ December 1981 by General Wojciech Jaruzelski. It concerns one of the largest sites of resistance in the country - Nowa Huta. I have presented what the arrest of the opposition activist in Nowa Huta looked like on the night of 12/13 December 1981 and I have presented the course of strike and its repression in the largest workplace in Cracow - in the Vladimir Lenin Steelworks in Nowa Huta.
\end{abstract}

Key words: Martial law, a strike, Nowa Huta, repression, internment, opposition activists.

In 2011 we celebrated the thirtieth anniversary of the imposition of martial law in Poland. "Martial law is still a current issue for Poland" wrote Jan Rokita in the preface to the book Martial Law in Małopolska (Zabłocki 1994, p. 6) by Wiesław Zabłocki. These relatively recent events are still present in the minds of many Poles who lived in those times. They are alive in the memory of the opposition activists, who were often interned, and their families. They are in the minds of the demonstrators who frequently jeopardized their health by participating in manifestations. Finally they are remembered by the families of people who in the years 1981-1983 and after the formal lifting of martial law (on the 22nd of July, 1983) were killed for political reasons.

In this paper I have presented the events of the first days of martial law in the Vladimir Lenin Steelworks (HiL) in Nowa Huta. According to the intentions of its creators Nowa Huta was to be a separate, exemplary socialist city. However it became, along with Gdańsk, one of the principal points of resistance in the country. Previously, in 1960 the events known as the Battles for the Cross occurred when Nowa Huta residents rebelled against the withdrawal of authority approval to build the first church in their district. In 1979, there was an attempt to "attack" the Vladimir Lenin monument located in the Aleja Róż. Also, the strike of 1988 proved the oppositional nature of the Youngest Sister of $\mathrm{Cracow}^{76}$, as Nowa Huta is sometimes referred to.

76 This was the title of the outdoor exhibition located in front of the Culture Centre in Nowa Huta in 2009. It was initiated by Adam Gryczyński;

http://www.jakiaparat.pl/najmlodsza_siostra_krakowa_druga_czesc_wystawy_plenerowej_ poswieconej_nowej_hucie,1242423416,1. 


\section{THE SIGNIFICANCE OF THE DATE $13^{\mathrm{TH}}$ DECEMBER 1981}

13 XII 1981 is one of the most significant, symbolic and controversial ${ }^{77}$ dates in the history of the PRL (Polish People's Republic). On that day, the First Secretary of the KC PZPR (Central Committee of the Polish United Workers Party) Polish prime minister and defense minister, General Wojciech Jaruzelski, without waiting for a resolution of the State Council (Dudek, Zblewski 2008, p. 309) announced the introduction of martial law throughout the country. Internment of "Solidarność" (Solidarity $)^{78}$ activists began, a curfew was introduced, telephones were cut off ${ }^{79}$, leaving the place of residence without a pass was banned, all borders, petrol stations and airports (Chwalba 2004, p. 407) were shut down and the publication of newspapers ${ }^{80}$ was suspended, because the authorities " out of necessity, limited the constitutional privilege of citizens - a universal access to comprehensive communication" ("Głos Nowej Huty" 1982, p. 1). The exceptions at the central level were the "Trybuna Ludu" ("Tribune of the People") - the press organ of the PZPR (Polish United Workers Party) and the "Żołnierz Wolności" ("Soldier of Freedom") (http://histmag. org/?id=6200). All organizations except the PZPR and its subordinated political parties, including the NSZZ "Solidarność" (Independent and Self-governing Trade Union "Solidarity") were suspended. It is worth noting that the only organization to be dissolved was the Independent Association of Students (5 I 1982) (Gliksman 2005, p. 76).

Preparations for

introduction of mar- Source: Satyra stanu wojennego 1983

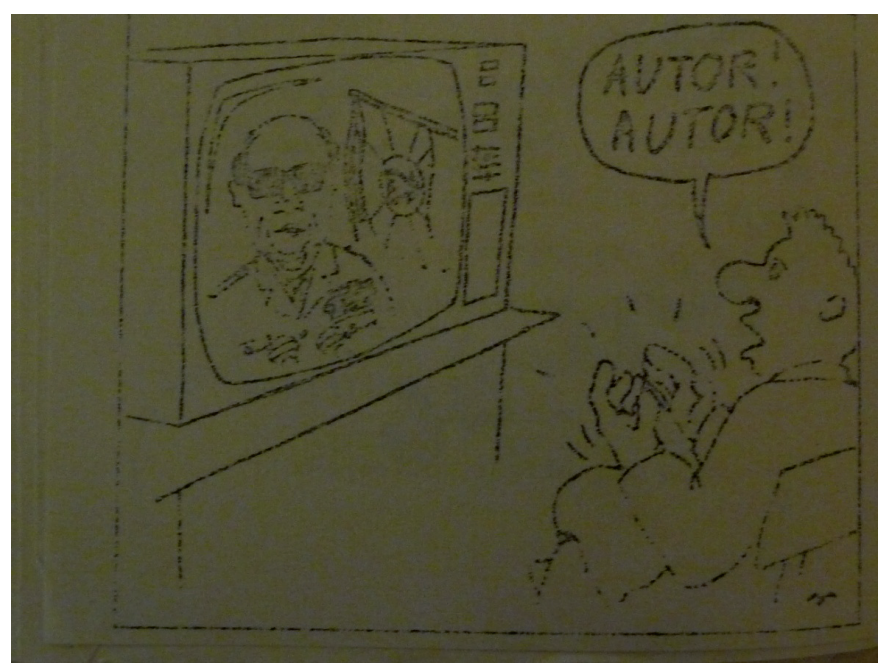

Fig. 1 AUTOR! AUTOR!

77 Discussions of the necessity of its introduction in Poland are still continuing. Nowadays historians are of the opinion that in December 1981 there was not a real threat of Soviet troops entering Poland. They also emphasize the illegality of Gen. W. Jaruzelski's decision. In accordance with the Constitution of the PRL (of 22 VII 1952) the State Council was not allowed to issue decrees during a session of the Parliament. Between 12-13 XII 1981 the Parliament was in session.

78 The people of Cracow were placed in the penitentiary in Wiśnicz Nowy and then they were sent together with others to Załęże near Rzeszów, Uherec, Łupkowa, Jastrzębia (Chwalba 2004, p. 408).

79 The network was restored in January 1982 but each caller heard a warning message "controlled conversation".

80 "Głos Nowej Huty", which I will cite in this work, did not appear for four months. In the first issue of 1982, which appeared on April 16, an article Kalendarium 18 tygodni was published informing about events in Nowa Huta, since mid-December 1981 until mid-April 1982. 
tial law in our country were already in process from October $1980^{81}$. The activists of Solidarity were aware of this. For example, the Malopolska Regional Board, mindful of the experiences of the so called Bydgoszcz crisis of March 1981, issued an Instruction in the event of a martial law (Bukowski 1991, p. 8) which predicted the sit-in.

\section{THE BEGINNING OF MARTIAL LAW}

From the beginning of December 1981 the situation in the country was growing more and more tense. It was no different in southern Poland. On December 1st ZOMO (Motorized Reserves of the Citizens' Militia) brutally beat the workers of the Małopolska Regional Board („Głos Nowej Huty” 1981, p. 1). The Regional Board wanted to inform the public about what had happened and demanded the opportunity for their representatives to appear on television. In the event of failure to meet this request a warning strike was considered. On December 12 the "Głos Nowej Huty" ("Voice of Nowa Huta") published an article entitled Will we go on strike 14th XII in Małopolska? („Głos Nowej Huty” 1981, p. 1).

We can therefore conclude that some people expected activity against the government. It is confirmed by the words of Jan Franczyk, who described the imposition of martial law in the following way: "Between Saturday and Sunday, something happened, something seemed to be hanging in the air, but nobody believed that the authorities would decide on such a drastic step" (Moja Nowa Huta. 19492009 wystawa jubileuszowa 2009, p. 146).

Maciej Mach 82 , another opposition activist, also pointed out: "In December of the year of eighty one, the situation was such, that everything seemed to indicate that something would happen (...). For some time it was common, that in front of the plant entire columns of riot police passed, transporters, these »kennels", maybe fifteen or seventeen cars (...). The Chairman of the Works Committee »Solidarity « from the Medical Academy, Dr. Kutyba just says that something will certainly happen because a directive has come through that says those who are up to it should be discharged from the hospital so that there are more beds available. He warned us saying that he felt it was preparation for some things that might occur. However the introduction of the martial law itself was a surprise to us. Nobody saw it coming. People would have behaved a bit differently" (Komperda 2009a).

The vast majority of society was not prepared for the introduction of martial law, which not only "shocked the population of our country, but also deeply rocked world public opinion" ("Acta Medica Cracoviensia Tempore Status Belli

81 The general staff started preparing in October 1980. On November 3rd of that year, the Deputy Minister of Internal Affairs General B. Stachura gave an order to begin organizing the crackdown under the code name "Wrzos" (heather), which sought the internment of nearly 13 thousand people (Dudek, Zblewski 2008, p. 308).

82 Since September 1980 he had co-founded the structures of the NSZZ "Solidarność" at the Autobody Sheets Faculty (Member of the Founding Committee, and from March 1981 the Commission Departments). Following the declaration of martial law, he participated as a member of the Strike Committee in the steelworkers strike in the HiL factory (13 - 15 December 1981). Since January 1982 he had co-founded the Salvation Committee of Solidarity and (since summer 1982) a secret managerial organization "Grot". After the arrests of members of both organizations in the autumn of 1982, he co-founded the Provisional Steelworkers Commission. At the same time he was a co-initiator and coorganizer of the Social Fund for Workers Assistance (Komperda 2009a). 
13 XII 1981 - 1982", p. 1). People suddenly found themselves in a completely different situation; they often did not know what had happened to interned family members or friends, strikes broke out ${ }^{83}$, there were fights with the services of $M O$ (Citizens' Militia), ZOMO (Motorized Reserves of the Citizens' Militia) and ORMO (Voluntary Reserves of the Citizens' Militia) as well as the armed forces.

One of the oppositionists of Nowa Huta, then twenty-three years old Leszek Jaranowski ${ }^{84}$ recalled many years later, in 2009: "We did not really know what martial law meant at all. Most people had no idea how it might end. However some, especially older people, maybe because of past experiences, had suspicions. Frankly it was an unknown quantity. However, each of us felt the need to protest. So we protested" (Komperda 2009b).

This, above mentioned, statement shows that people were mainly motivated by emotions and they were not aware of what was in store for them. Certainly many people were worried about forthcoming events, however, L. Jaranowski mentioned that only one man in his department did not support the strike and withdrew from these activities.

The announcement of martial law began the process of internment of opposition activists across the country. On the strength of an order signed by the Deputy Minister of Home Affairs General Bogusław Stachura and the Minister of Justice, Sylwester Zawadzki fifty-two detention centers were established in places such as: Białołęka, Gołdap, Jawor, Łowicz, Strzebielinek (a place of internment for the activists of "Solidarity" headquarters), and Załęże (Roszkowski 2003, p. 49), where activists from Małopolska were sent from their earlier detention centre in Wiśnicz Nowy. Territorial divisions of the SB (Security Service) had already received their first orders on December $12^{\text {th }}$ at approximately 16:00.

Also the opposition activists in Cracow did not avoid internment. Waldemar Bukowski stated that on the night of the 12/13 ${ }^{\text {th }}$ December, 1981, 94 opponents were interned in Cracow (Bukowski 1991, p. 9). By the end of 1981 the number had risen to 120 (Kronika Krakowa 1996, p. 467) and, according to Andrzej Chwalba, by April 30, 1982 this number had increased to 326 (Chwalba 2004, p. 408).

83 Małopolska was the region where, in mid-December 1981, many factories were on strike. The most important strikes, apart from the Steelworks in Nowa Huta, occurred in the district of Cracow, in the MPK - Municipal Public Transport Service (December 13-15), the "Montin" company (14-16 December), "Telpod" (14-16 December), "Armatura" (14 December), CeBeA (December 14) and in smaller centres, such as in the Iron Foundry in Charsznica (14 December) and subsidiaries of HiL in Bochnia (13-15 December). This illustrates the scale of the phenomenon (Bukowski 1991, p. 9).

84 He worked in the Transportation Equipment Factory - National Aircraft Factory in Cracow, where since September 1980, he had co-founded structures of "Solidarność". He was the chairman of the Machining Center Faculty Commission WSK - PZL. On the $14^{\text {th }}$ December 1981, as the chairman of the Strike Committee, he organized a strike of the workers of WSK-PZL. His main field of independent activity was an underground printing press. From 1982, he was the author, editor, printer and organizer of the distribution of many magazines, including "Jesteśmy, będziemy...", " Miscellanea", "Serwis Informacyjny RKW / RKS", "Hutnik" (from 1983). In addition he organized the distribution of an independent press coming to Cracow from the whole of Poland. In Cracow he founded and ran several libraries of independent publications, including one in WSK-PZL and the Polish Academy of Sciences. On the $5^{\text {th }}$ of November 1982 he was called up for a few months for national service in a Special Military Camp in Czerwony Bór. Throughout his opposition activities he was repeatedly stopped and questioned by the Secret Service (Komperda 2009b). 
A similar fate was suffered by J. Franczyk. His situation on the night of the $12 / 13^{\text {th }}$ December, 1981 is described in the words:

"I went to sleep around 23.30 and it may have been 23.45 when someone knocked on the door. I got up and asked:

- Who's there?

- Militia

So I, according to the instructions learned during my time in the opposition movement, say:

- Gentlemen, please come at six in the morning. Then I will let you in, it is night-time now and I will not allow you to enter.

- But this is an important issue, we have a warrant.

- Please come at six o'clock in the morning.

- We will prise the door open.

- Then prise it.

Then they left, but I felt that it was not good. I made some coffee and my parents woke up. My mother asked me what was happening and my father was also slightly nervous. I said that the militia was here a moment ago, that they said they would prise open the door, but left. It took maybe half an hour before they came back and said that I need to open up, otherwise they would break down the door. My father started shouting angrily that he would smash the head of the first one to enter with an axe. This was later described in detail by one of the officers. I have discovered it in one of the documents received from the IPN (the National Remembrance Institute). They brought a large jemmy and forced the door open. Remembering his father's words about the axe, they entered with guns, but as they saw me sitting quietly in a chair and sipping coffee, they put the weapons down. Then they served a warrant, explained that it was martial law and that I was detained. I said goodbye to my parents, telling them that probably in a few days they would find out what happened to me" (Moja Nowa Huta. 1949-2009 wystawa jubileuszowa 2009, p. 146).

The story of J. Franczyk, who was interned in New Wiśnicz presents what the first hours of martial law looked like from the perspective of an oppositionist. A detectable atmosphere of tension only highlights the courage of people like J. Franczyk. They had no idea what might happen to them as is evident in the last sentence of the quoted account, although they earlier had tried to prepare themselves in case of internment "according to the instructions learned during their time in the opposition movement" (Moja Nowa Huta. 1949-2009 wystawa jubileuszowa 2009, p. 146). In my opinion, the fear of the internees and their relatives could have been intensified due to the fact that the events I'm referring to took place in winter. In the second half of December 1981, temperatures reached several degrees below zero and the internees and their families did not know where they would be taken, or what the conditions there might be.

Activists of "Solidarity", who evaded detention organised strikes throughout Małopolska (Galicia). The most important one took place in the Vladimir Lenin Steelworks in Nowa Huta. Seven thousand people participated in it (http:/ / www.ipn. gov.pl /ftp/wystawy/nowa_huta/html/wstep.html\#stanwojenny). In total over 
two work shifts approximately 10 thousand were on strike. After a failed attempt by militia to arrest the activists of $K R H$, "S" staying over the night duty at the union's offices, Stanisław Handzlik called for a sit-in strike, "without time limit". The strike on the crusher began at about 2.30 a.m. By the morning of December 13, all consulting departments of HiL (Vladimir Lenin Steelworks in Nowa Huta) had been on strike.

At 1 pm its representatives met with the leadership of the HiL Plant (http:/ / www. ipn.gov.pl/ftp/wystawy/nowa_huta/html/wstep.html\#stanwojenny) in order to start the first talks on the situation. From 3 pm the first resolution of the Strike Committee signed by its chairman Mieczysław Gil came into force. Under its regulation, Komisja Robotnicza Hutników (Comission of Steel Mill Workers) took over the rights and obligations of the shattered Regional Board of the NSZZ "Solidarność". It was emphasized that this decision is valid until further notice (Bukowski 1991, p. 41).

Later that same evening, M. Gil, the chairman of the HiL Strike Committee wrote a letter to the families of the strikers:

"Dear our relatives, families,

Mothers, fathers, our children.

To the declaration of martial law Nowa Huta replied with the strike. This is the response to the arrest of our activists. This strike is a basic union duty and a basic human duty as outlined in the articles of association.

We wanted and we want the agreement of the whole nation. IT IS NOT US who announced martial law. We all know that the situation in the country and the city did not require such a measure: there was neither anarchy nor terror. Society invariably showed exemplary composure and patience (...). The activity of the Solidarity Trade Union, which tried to save the country, is suspended. A strike remained as the last means of protest (...). The condition of the agreement is recognition of the further legal activity of the NSZZ SOLIDARNOŚĆ and the safety of its activists. There will be neither a cooperation nor the possibility of an agreement until we are all together with our activists including the National Commission. The release of all internees, and cessation of arrests is a fundamental and irrevocable prerequisite. Relatives and friends, we appeal for SOLIDARITY, mutual assistance, looking after the families of the absent ones, for composure and dignity in the face of repression. LET US NOT FORGET THE TIME OF SOLIDARITY. We made mistakes, but we won for a short time the disclosure of the truth about the harm of our homeland and about the sources of its strength. THE FIGHT LASTS AND WILL LAST. We will never fall into passivity and hypocrisy, no one signs disgraceful requests for clemency. Let us be faithful to our conscience and conviction no matter what happens.

December 13, 1981 the HiL Strike Committee.

6.30 pm" (Bukowski 1991, p. 40).

M. Gil stressed that in December 1981 there was no need to introduce martial law. For many years an argument was repeated that its introduction had prevented the entry of Soviet troops into Poland. Today we can say with certainty that such fears were not justified. On December 10, 1981, General W. Jaruzelski informed the Soviet authorities of the decision to introduce martial law in Poland and asked for a guarantee of military assistance should the situation in our country become critical. The Soviets refused to provide it (Dębska 2006, p. 7). 
The letter from the Chairman of the HiL Strike Committee had to raise the spirits of both the strikers and their families or loved ones of those who were interned. Their release became a primary goal of the protest. The families were encouraged to mutual assistance. It was demanded that the Trade Union NSZZ "Solidarność", whose activities were suspended be lawfully restored. Appeals were made for mutual solidarity and help among workers. Lack of cooperation with the authorities was declared on the grounds that they had significantly abused their powers by limiting the freedom of citizens, whose actions in the NSSZ "Solidarność" they defined as terror. It was emphasized that it was the state authority that was responsible for the economic situation in the country and for the deepening crisis. It was stressed that people had tried to adjust to conditions from before the 13 XII 1981.

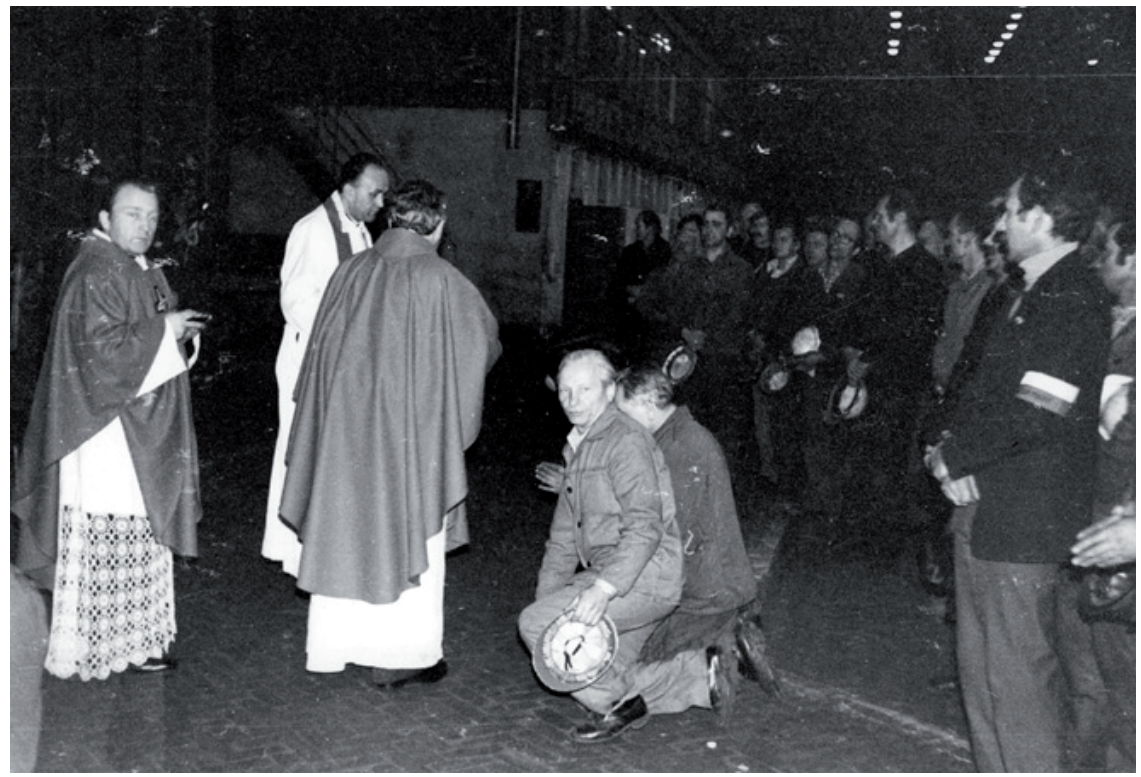

Fig. 2. A mass during the strike in the Car Body Sheet Mill of HiL on the 13 XII 1981 celebrated by Jan Bielański and Józef Bielański; photo, Józef Fularz

Source: http://www.ipn.gov.pl/ftp/wystawy/nowa_huta/html/plansza14d.html). The photo was displayed in the exhibition Nowa Huta 1949 + opened from 25.01-04.04.2012 in the branch of the Cracow Historical Museum - The history of Nowa Huta. It comes from the archives of the Cracow Branch of the National Remembrance Institute.

\section{THE SUCCESSIVE DAYS OF STRIKE AT THE STEELWORK HIL}

On December 14th at 3.30 pm the Komitet Strajkowy Hutników (Steelworkers Strike Committee) issued Resolution No. 3 in which M. Gil asked, "Against whom is this war to be?" (Bukowski 1991, p. 42). He claimed that the HiL Strike Committee: "cannot find justification for the imposition of martial law in the absence of an external threat" (Bukowski 1991, p. 42). On the second day of the strike the HiL Strike Committee therefore refused to take up any talks with the government, was determined to fight the militia and ready for a hunger strike. Its goal was to achieve the release 
of all those interned the day before. However, in the afternoon there was a meeting of the Strike Committee with a representative of the National Defence Committee in the presence of the managing director of the HiL Steelworks („Głos Nowej Huty” 1982, p. 2). The strikers wanted the situation to become known to the wider public. On December 15th the Komitet Strajkowy NSZZ Solidarność Matopolska (Strike Committee NSZZ "Solidarność" Matopolska) issued An Appeal to the United Nations, (Bukowski 1991, p. 44-45) in which it stressed the illegality of the activities of the Polish authorities, referring to Article No 31 of the Constitution and called for compatriots to help; its aim was therefore to provide information on contemporary events in Poland in general. Let us remember that during this period it was difficult to communicate with anyone because of the censorship of correspondence and the suspension of the telephone network. It was also difficult to travel to another city. People had limited access to reliable information from other regions of the country.

On the initiative of S. Handzlik ${ }^{85}$ and a student Stanisław Tyczyński ${ }^{86}$ Radio Free Poland was launched, which after a few months was transformed into Solidarity Radio Małopolska. In December 1981, the radio broadcast "first of all the announcements; it was emphasised there that we speak to you Ladies and Gentlemen from a patch of free Poland, which means we are here on the Steelworks premises"(Komperda 2009c). The broadcast area was about $5 \mathrm{~km}$, therefore, covered only a part of Nowa Huta, but still it become one of Nowa Huta's symbols of the fight against the dictates of the central government. By broadcasting patriotic songs (like "Legion") it sustained the spirits of the weary and frightened citizens of the youngest district of Cracow.

On the same day, at $4 \mathrm{pm}$, talks between representatives of the Strike Committee and a plenipotentiary of Komitet Obrony Kraju (the National Defence Committee) were resumed with a unilateral decision made to have the strike finished by 6 pm („Głos Nowej Huty" 1982, p. 2). The strikers, however, did not cease their activities.

On the December $15^{\text {th }}$ the situation remained very tense. The atmosphere of the day is reflected in the words of one of the anonymous workers of Nowa Huta:

"Everybody was terribly afraid. We were ready for anything, even death. But there was nothing to fight with. No one gave any orders. Several times alarms sounded, that they were coming. The assault started at one o' clock. The attack was heralded throughout Nowa Huta by sirens.

We created a circle ${ }^{87}$. All the time Hudaszek and Bortnowska talked to us through a megaphone. They stood on those metal stairs. They did not want to enter the circle. They said to not offer resistance, to gather together, to look after colleagues. Bortnowska, especially, kept our spirits up; she joked and laughed and asked why we were so scared" (W stanie 1984, p. 14).

And this is how the day is remembered by one of the participants of the strike at the Steelworks: "In the front of the hall there were strong young men arranged and behind tightly pressed stood the rest with women in the middle. So that they

85 Deputy Chairman of the KRH Steelworkers Commission. He organized the steelworkers strike, on 13 - 16 December 1981. After its suppression he was in hiding for several months. During this time he co-organised the secret structures of "Solidarność" and was one of the signatories of the documents of the Matopolska Regional Executive Committee.

86 One of the founders of Radio RMF-FM.

87 Such were recommendations of the HiL Strike Committee 
could not tear us away individually. We stood and sang. Hours went by and nobody came. Tension and nervousness affected us all. It was cold. Then someone said it does not make sense to stand like this and so women and guests should go to the dispatching room. A moment later a boy came from another department and said that it was all over with them, that they stood just as we did and when the ZOMO militia ordered them to disperse, they did not comply. They pulled out the first one and started to beat them. Then the people left" (W stanie 1984, p. 15).

Both of these accounts reflect the atmosphere of the last day of the strike at HiL. Its participants remained in suspense, they were afraid of an attack by police officers. People were aware that in the past, emergency services had fired at the workers $^{88}$. This time strikes were spread across the entire country, not just individual parts of its territory as in 1970 and 1976. In fact on the same day, at the Wujek coal mine, seven miners were killed and two more died several days later. That bloodshed has become a reason for demonstrations held later on the sixteenth day of each month. It has also become one of the symbols of martial law in Poland once again in the history of the PRL (Polish People's Republic) people were killed for political reasons. It was feared that such a course of events might take place in Nowa Huta, which became the main bastion of "Solidarity" in southern Poland. The words of the worker, I quoted above, although certainly very emotional, confirm that it was assumed that deaths might occur in the Steelworks (Wstanie 1984, p. 14). On December $16^{\text {th }}$ at $2 \mathrm{pm}$ there was an attack on the strikers. In the face of an attack by ten T-54 tanks, which battered the wall around the Steelworks gate, as well as over two thousand soldiers and 2150 ZOMO officers (Chwalba 2004, p. $411)$, the strikers decided to discontinue their operation.

How was the course of the pacification of the HiL? Let's give voice to two participants. M. Mach, who spoke about the conduct of the soldiers: "In our case there wasn't any violence or beatings on their part. I mean, there was aggression in the sense of intimidation: just shouting, screaming, some hooting. However, they were afraid probably because there was a rumor that we would defend ourselves. Therefore, they were scared we might start gathering different things, etc. So they yelled, so to say, to stay calm" (Komperda 2009a).

There wasn't however complete agreement on the question of how to behave in the case of a militia intervention. The above-mentioned S. Handzlik spoke about it years after: "We argued about which formula to adopt. Should it be an active resistance - should we arm ourselves with whatever ${ }^{89}$ and go against the tanks, against machine-guns etc., or recognize that it is not yet the end of the world, not the end of "Solidarność" that it should be experienced at the least cost, with the smallest sacrifices. Luckily the second variant of passive resistance won out. What it involved has been explained above" (Komperda 2009c).

It seems that it was a wise and responsible decision which was confirmed by the above-quoted strikers. Thanks to it, as opposed to what happened at the Wujek mine, there were no fatalities.

88 It seems that the memory of December'70 and especially June' 76 were on the minds of the workers.

89 Stanislaw Handzlik stressed that young people from the Mill, where their strike centre was located, were preparing Molotov cocktails to defend their patch of liberty against the police and army charging vehicles. 
On December $16^{\text {th }}$, a certain stage of power confrontation between authorities and their opponents came to an end. The strikers in the Steelworks, however, suffered some consequences - a disciplinary dismissal of two thousand HiL workers. The next day there was a demonstration in the centre of Cracow. In St. Mary's Church a mass was held commemorating the anniversary of the events of December 1970 (Dudek, Marszałkowski 1992, p. 176). In front of the church protesters chanted: "Wrona skona" ("The crow will die") and "Jaruzelski zdrajca" ("Jaruzelski the traitor"). They were driven away by water cannons, which were used in spite of the below freezing temperature (Chwalba 2004, p. 411). The Nowa Huta activists of "Solidarność" had to change their strategy. The upcoming Christmas was not going to be happy for them. A lot of employees of the largest plant in Nowa Huta had lost their source of income and their future became increasingly uncertain.

The following months proved the oppositional character of Nowa Huta. Residents of the youngest district of Cracow, took up both passive and active resistance. The passive defiance manifested itself in boycotting the official press or the evening news which distorted the truth, painting slogans on buildings ${ }^{90}$ (Dudek, Marszałkowski 1992, p. 195), creating an underground press and distributing illegal leaflets. As is clear from the documents of the Cracow branch of the National Remembrance Institute, there appeard in Nowa Huta several underground magazines such as: "Obserwator wojenny" ("The Observer of War") signed by the MKS (Inter-factory Strike Committee) Nowa Huta, "Solidarność Zwycięży" ("Solidarity Will Win") and "Montinowiec" signed by the organization Press Arrangement "Solidarity Will Win" at the MKS Nowa Huta and "Hutnik" ("Steelworker") issued by the members of the NSZZ "Solidarność" in HiL (Plany i sprawozdania Wojewódzkiego Urzędu Spraw Wewnętrznych w Krakowie, p. 41-42).

From June of 1982, Nowa Huta, was a place of the greatest patriotic demonstrations in Cracow, which often ended in many hours of street fights. They resulted in detention" , multiple injuries to the demonstrators ("Acta Medica Cracoviensia Tempore Status Belli 13 XII 1981-1982") and damaged public utility buildings such as the fourth MO (Citizens' Militia Station) in Bieńczyce, which was pelted with stones on June 13th, 1982 (Dudek, Marszałkowski 1992, p. 188).

Street incidents occurred most often on the thirteenth (the monthly anniversary of the imposition of martial law) and sixteenth (the monthly anniversary of the battle in the Wujek Coal Mine) day of the month. The demonstrations were also organized on the national holidays, not recognized by the communist regime (3 May and 11 November) and the anniversaries related to "Solidarność". Particularly fierce fighting took place on August $31^{\text {st }} 1982$, the second anniversary of signing the August agreement in Gdańsk. According to Antoni Dudek and Tomasz Marszałkowski the demonstrations were held in 66 cities throughout 34 of the then 49 existing provinces (Dudek, Marszałkowski 1992, p. 190). The most tragic events took place in Lublin - 3 people paid with their lives for participation in those riots. Also in Cracow and

\footnotetext{
90 We find there information about slogans painted in February 1982 in the following Housing Developments: Stalowe, Hutnicze, Ogrodowe, Centrum "A", Kolorowe, Centrum " $B$ " and Centrum " $C$ ".

91 For example for participating in demonstrations on the $31^{\text {st }}$ August 1982 in Nowa Huta and Śródmieście, 259 people were detained (Dudek, Marszałkowski 1992, p. 195).
} 
Nowa Huta street fighting occurred which caused significant damage. The photo below was taken by one of the demonstrators in Nowa Huta.

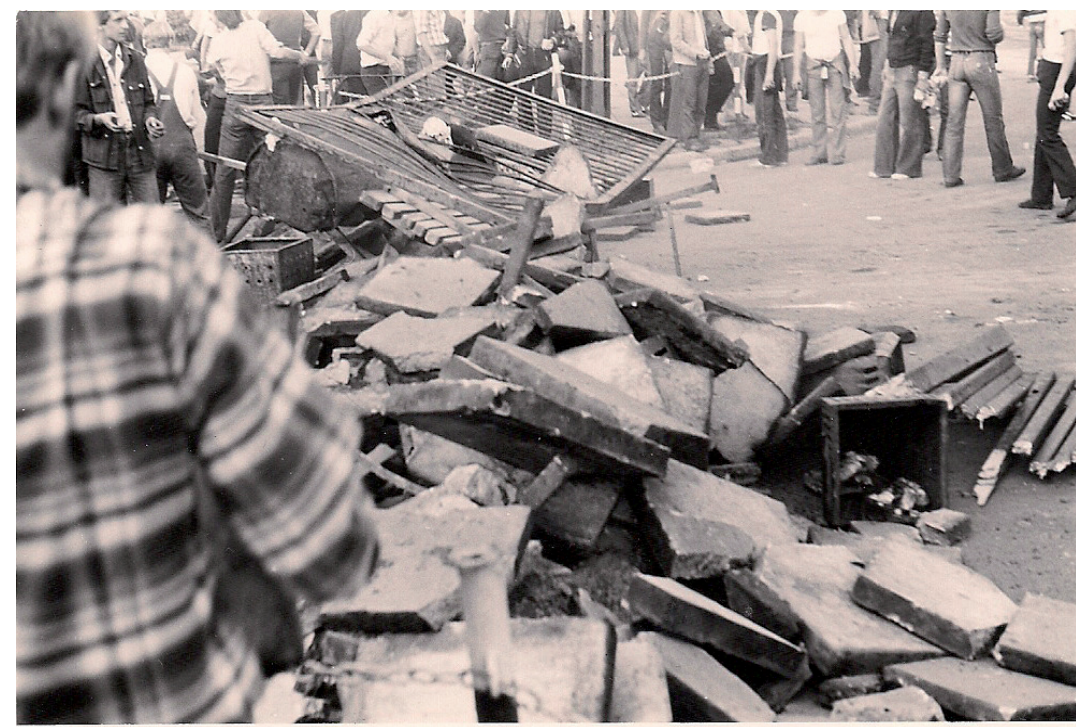

Fig. 3. 31 sierpnia 1982 r. w Nowej Hucie; in the possesion of Zdzisław Szczupak

Source: Photo from the private collection of Z. Szczupak

Unfortunately there were deaths. In April 1982 there was a tragic event. Beaten by the riot police $(Z O M O)$ a 22-year-old worker of HiL, Andrzej Szewczyk, was fighting for his life for seven weeks but never regained consciousness. He was beaten because he came home after the curfew. He died in early June, and his father said bitterly: "I fought at the front, I received many awards, including the Virtuti Military Cross, and my last cross was this one on the grave of my son" ("Solidarność Zwycięży" 1982, p. 2). Szewczyk was the first fatality of martial law in Cracow.

In October 1982 a 20-year-old, Bogdan Włosik, was killed and in May 1983 a 29-year-old, Ryszard Smagur (http:/ / www.bialo-czerwona.pl/stan_wojenny/ ofiary.htm). Their funerals become manifestations of opposition against the situation in the country. Thousands of people took part in them.

A few days after the murder of B. Włosik "Gazeta Krakowska" ("The Cracow Newspaper"), in the article The Absolute Majority of the Nowa Huta Inhabitants does not Want to Have Anything to Do With the Riots, reported that discipline in workers' hostels and boarding houses had tightened, paying particular attention to the organization of activities for young people ("Gazeta Krakowska" 1982b, p. 1-2). The article was intended to present that the street-protesting opponents of the system were in a tiny minority and most of the Nowa Huta residents wanted peace and did not want the street incidents to be repeated in the future.

Nowa Huta remained an unruly, rebellious city not only until the lifting of martial law, but until the late nineteen eighties of the XX century (Kasprzycki 2003, p. 34-44). 
Marek Lasota PhD, a director of the IPN in Cracow emphasized the oppositional nature of the interesting us district of Cracow in the movie Dymy nad Arka Pana (Smoke over the Lord's Ark)92 saying: "In the 80's this life of solidarity, this struggle, also physical, because it was a physical fight, let's not have illusions about it, is concentrated mainly in Nowa Huta and this phenomenon is extremely symbolic" (the film produced by MH.MEDIA.PL for TVP Cracow in 2009; the script and production: Miłosz Horodyski, excerpt 4:28-4:42).

In order to understand this statement we should go back to the late 40's and early 50's, when Nowa Huta was built. In the plans of its creators it was to become the model of a socialist city, a symbol of the new Polish political system. In reality, however, this youngest district of Cracow, during the whole period of PRL period, resisted that political system in our country. The strike in the HiL in the early days of martial law was clear evidence of that. The future showed that this occurrence was not the last one.

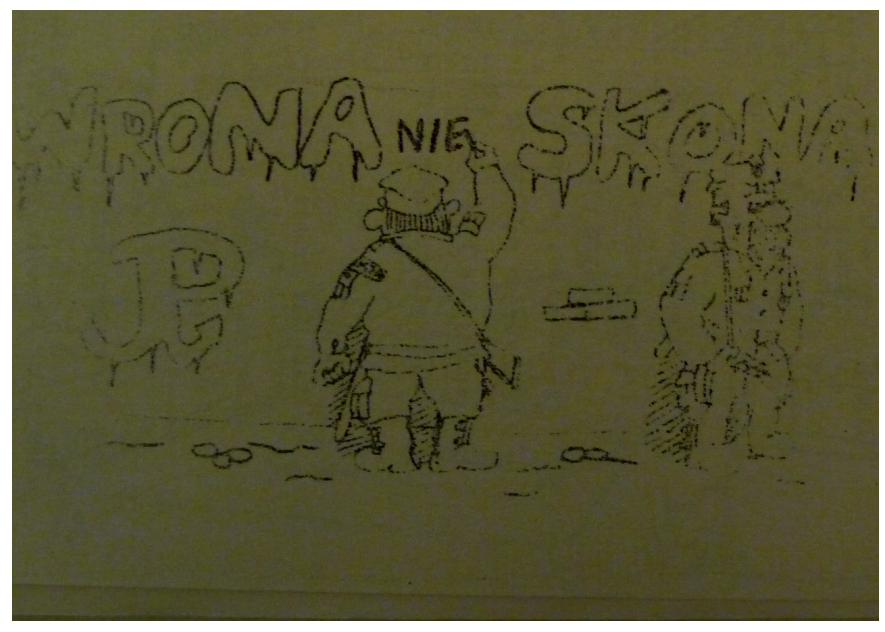

Fig 4. WRONA nie SKONA

Source: Satyra stanu wojennego 1983

\section{SOURCES}

An interview with M. Mach conducted by J. Komperda 5 X 2009a, in the possession of the PRL Museum in Cracow.

An interview with L. Jaranowski conducted by J. Komperda 20 XI 2009b, in the possession of the PRL Museum in Cracow.

An interview with S. Handzlik conducted by J. Komperda 2 IX 2009c, in the possession of the PRL Museum in Cracow.

Photo from the private collection of Z. Szczupak.

\section{BIBLIOGRAPHY}

“Acta Medica Cracoviensia Tempore Status Belli 13 XII 1981 - 1982” (1983), Vol. 1, Komitet Oporu Społecznego Służby Zdrowia, Kraków.

Bukowski W. (1991), Solidarność Małopolska w Podziemiu, Universitas, Kraków.

Chwalba A. (2004), Dzieje Krakowa. Kraków w latach 1945-1989, Vol. 6, Wydawnictwo Literackie, Kraków.

92 The film produced by MH.MEDIA.PL for TVP Cracow in 2009. The script and production: Milosz Horodyski. The title refers to street fighting in the vicinity of the Bieńczycki Church of Our Lady the Queen of Poland colloquially called the Ark of the Lord, which took place throughout the whole decade of the 1980's. 
Dębska A. (2006), Stan wojenny. Ostatni atak systemu, Ośrodek Karta, Warszawa.

Dudek A., Marszałkowski T. (1992), Walki uliczne w PRL 1956-1989, Wydawnictwo GEO, Kraków.

Dudek A., Zblewski Z. (2008), Utopia nad Wista. Historia Peerelu, Wydawnictwa Szkolne PWN, Wydawnictwo „Park”, Warszawa - Bielsko-Biała.

“Gazeta Krakowska" 183 (11519), 22-24.10.1982.

Gliksman A. (2005), Solidarność Małopolska. Kalendarium 1980-2005, Wydawnictwo Zarządu Regionu Małopolska NSZZ „Solidarność”, Kraków.

“Głos Nowej Huty" (1981), 50 (1302).

"Głos Nowej Huty" (1982), 1 (1303).

Kasprzycki R. (2003), Opozycja polityczna w Krakowie w latach 1988-1989, Księgarnia Akademicka, Fundacja Centrum Dokumentacji Czynu Niepodległościowego, Kraków.

Kronika Krakowa (1996), Wydawnictwo „Kronika”, Warszawa.

Moja Nowa Huta. 1949-2009 wystawa jubileuszowa (2009), Muzeum Historyczne Miasta Krakowa, Kraków.

Plany i sprawozdania Wojewódzkiego Urzędu Spraw Wewnętrznych w Krakowie, IPN Kr 056/98/2/DVD/1.

Roszkowski W. (2003), Najnowsza historia Polski 1980-2002, Świat Książki, Warszawa.

Satyra stanu wojennego (1983), Spółka Edytorska „NN”, Lublin.

Sekretariat Wojewódzkiego Komitetu Obrony Kraków. Zbiór protokołów z posiedzeń WKO wraz z materiatami stanowiacymi przedmiot obrad (16.03-26.04.1982), IPN Kr 210/121.

“Solidarność Zwycięży" 4, 27.06.1982.

W stanie (1984), Karta, Warszawa.

Zabłocki W. (1994), Stan wojenny w Małopolsce, Wydawnictwo Arcana, Kraków.

\section{NETOGRAPHY}

http://www.bialo-czerwona.pl/stan_wojenny/ofiary.htm, retrieved: 26.04.2012.

http:/ / histmag.org/?id=6200, retrieved: 27.04.2012.

http://www.ipn.gov.pl/ftp/wystawy/nowa_huta/html/wstep.html\#stanwojenny, retrieved: 23.11. 2011.

http://www.ipn.gov.pl/ftp/wystawy/nowa_huta/html/plansza14d.html, retrieved: 24.11.2011.

http://www.jakiaparat.pl/najmlodsza_siostra_krakowa_druga_czesc_wystawy_plenerowej_ poswieconej_nowej_hucie,1242423416,1, retrieved: 26.04.2012.

\section{FILMOGRAPHY}

Dymy nad Arka Pana, produced by MH.MEDIA.PL for TVP Cracow in 2009, the script and production: Milosz Horodyski. 